\title{
Toxicity of Ageratum conyzoides extract against Spodoptera sp
}

\author{
Dian Ekawati Sari ${ }^{1 *}$, Rahmawati Arma $^{1}$ \& Bakhtiar ${ }^{2}$ \\ ${ }^{1}$ Program Studi Agroteknologi, Universitas Muhammadiyah Sinjai, Sinjai, Sulawesi Selatan. \\ ${ }^{2}$ Balai Proteksi Tanaman Pangan dan Hortikultura, Maros, Sulawesi Selatan. \\ *Corresponding Author : dianekawatisari@ rocketmail.com
}

Received October 11, 2021; revised January 21, 2022; accepted January 22, 2022

\begin{abstract}
Spodoptera sp. is the main pest in food crops and horticulture that can reduce production by up to $80 \%$ Control is carried out only using chemicals that can damage the environment and impact human health. so, efforts are needed for pest control by utilizing Ageratum conyzoides extracts that are more environmentally friendly. This study aims to find out the effects of $A$. conyzoides extract on Spodoptera sp. pests on rice plants. The study consisted of plant extraction of A. conyzoides, rearing of Spodoptera sp. and application of A. conyzoides extract on Spodoptera sp. The concentrations used are 1\%, 1.5\%, 2\%, $2.5 \%$, $3 \%$ and control. The results showed that the best treatment was obtained at concentrations of $3 \%$ and $2.5 \%$ with mortality percentages of $90 \%$ and $96.67 \%$. The results of probit analysis obtained $\mathrm{LC}_{50}$ and $\mathrm{LC}_{90}$ concentrations of $1.59 \%$ and $2.53 \%$, respectively, analysis at 72 hours after treament. Therefore, A. conizoides extract potential to be used for controlling Spodoptera sp.
\end{abstract}

Keywords: Spodoptera sp, A. conyzoides, Mortality

\section{ABSTRAK \\ Toksisitas Ekstrak Ageratum conyzoides L. terhadap Spodoptera sp}

Spodoptera sp. merupakan hama utama pada tanaman pangan dan hortikultura yang dapat menurunkan produksi bahkan gagal panen jika tidak dilakukan pengendalian. Pengendalian yang dilakukan hanya menggunakan bahan kimia yang dapat merusak lingkungan dan berdampak terhadap kesehatan manusia. sehingga, diperlukan upaya untuk pengendalian hama tersebut dengan cara pemanfaatan ekstrak Ageratum conyzoides yang lebih ramah lingkungan. Penelitian ini bertujuan untuk mengetahui pengaruh dari ekstrak A. conyzoides terhadap hama Spodoptera sp. pada tanaman padi. Penelitian ini terdiri dari ekstraksi tanaman A. conyzoides, pembiakan Spodoptera sp. dan aplikasi ekstrak A. conyzoides pada Spodoptera sp. Konsentrasi yang digunakan yaitu $1 \%, 1.5 \%, 2 \%, 2.5 \%, 3 \%$ dan kontrol. Hasil penelitian menunjukkan bahwa perlakuan terbaik didapatkan pada perlakuan konsentrasi 2,5\% dan 3\%dengan persentase mortalitas masing-masing 90,0\% dan 96,67\%. Hasil analisis probit didapatkan $\mathrm{LC}_{50}$ dan $\mathrm{LC}_{90}$ masing-masing konsentrasi $1,59 \%$ dan 2,53\% pada pengamatan 72 jam setelah perlakuan. Oleh karena itu, ekstrak A. conizoides berpotensi digunakan untuk pengendalian Spodoptera sp.

Kata Kunci: Spodoptera sp, A. conyzoides, Mortalitas.

\section{PENDAHULUAN}

Spodoptera sp. merupakan hama penting dengan kisaran inang yang luas dan terseber dibeberapa negara. Hama tersebut memiliki sifat polifagus dan berpotensi menjadi hama utama pada tanaman pangan dan hortikultura. Kehilangan hasil akibat serangan $S$. litura dapat mencapai $80 \%$, bahkan puso jika tidak dikendalikan (Marwoto \& Suharsono, 2008). Spodoptera sp. dapat menyerang tanaman pada setiap fase pertumbuhan tanaman inangnya. Pengendalian hama yang banyak dilakukan petani saat ini yaitu pengendalian dengan menggunakan pestisida sintetik yang akan mengakibatkan beberapa masalah terhadap lingkungan dan manusia (Arivoli \& Tennyson, 2013).

Salah satu alternatif pengendalian yang dapat dimanfaatkan adalah penggunaan ekstrak tumbuhan. Pemanfaatan ekstrak tumbuhan untuk pengendalian hama sangat bagus karena ekstrak tumbuhan memiliki sifat dengan berbagai jenis efek terhadap hama. Penggunaan ekstrak tumbuhan tidak hanya menyebabkan kematian namun dapat juga dapat bersifat detterent, repellent, atraktan, ovicidal, dan penghambat pertumbuhan serangga. Oleh karena itu, perlu dilakukan pengujian tanaman-tanaman yang dapat dimanfaatkan oleh petani dalam melakukan kegiatan pengendalian hama. Pemanfaatan ekstrak tanaman merupakan pengendalian yang relative aman dan ramah lingkungan karena tidak menghasilkan residu dan dapat dengan mudah terurai. Selain itu, ekstrak tumbuhan dapat dimanfaatkan oleh petani tanpa harus mengeluarkan biaya besar. Pengaruh senyawa-senyawa kimia tanaman terhadap serangga dikemukakan oleh Nordlund et al. (1981) dan Sari (2014) bahwa kimia tanaman dapat berperan sebagai arrestan, attractan, repellent, stimulant dan detterent.

Potensi pemanfaatan ekstrak tanaman sebagai pengendali organisme pengganggu tanaman (OPT) masih sangat besar sehingga perlu adanya pengujian tanaman untuk mengetahui potensinya dalam pengendalian OPT tersebut. A. conyzoides merupakan salah satu tanaman yang dapat digunakan sebagai alternatif pengendalian OPT, karena mengandung metabolit sekunder. A. conyzoides 
memiliki kandungan flavanoid sebesar 21,24 mg yang diduga dapat digunakan sebagai sumber pestisida nabati (Ayun et al., 2020). Ekstrak A. conizoides dilaporkan bersifat anti jamur dan anti serangga (Kamboj \& Saluja, 2008; Chahal et al., 2021). A. conyzoides dengan pelarut metanol dapat menyebabkan efek penghambat peletakan telur, lama hidup imago repellent dan ovicidal pada hama Paraeucosmetus pallicornis (Sari, 2014).

A. conyzoides juga mampu menyebabkan efek repellent dan feeding deterrent pada hama Tribolium castaneum dan Sitophilus oryzae (Amelot et al., 2003). Aktivitas insektisida A. conyzoides terhadap hama Rhyzopertha dominica menyebabkan mortalitas hama tersebut mencapai 88,67\% dalam jangka waktu 24 jam setelah aplikasi (Moreira, 2007). Aplikasi ekstrak A.conyzoides pada larva Athalia proxima dan larva Spodoptera litura menyebabkan mortalitas sebesar $93.33 \%$ dengan konsentrasi $5 \%$ pada jam pemgamatan 72 jam setelah aplikasi ekstrak (Yadav and Patel, 2017). Berdasarkan uraian diatas maka penelitian ini bertujuan untuk mengetahui efek dari ekstrak tanaman A. conyzoides terhadap Spodoptera sp.

\section{METODE PENELITIAN}

Penelitian ini dilaksanakan pada bulan April sampai Agustus 2018 di Laboratorium Pestisida dan Bahan Alami Tanaman, Departeman Hama dan Penyakit Tumbuhan, Universitas Hasanuddin kemudian dilanjutkan di Laboratorium terpadu Universitas Muhammadiyah Sinjai. Pengujian toksisitas ekstrak A. conizoides terhadap Spodoptera sp. disusun dalam rancangan acak lengkap (RAL). Ekstrak A. conyzoides diuji terhadap larva Spodoptera sp pada 5 taraf konsentrasi yaitu :, $1 \%, 1,5 \%, 2 \%$, $2,5 \%, 3 \%$ dan kontrol yang diulang sebanyak 3 ulangan. Data kematian serangga uji yang didapatkan dianalisis menggunakan ANOVA dalam rancangan acak lengkap kemudian dilanjutkan dengan uji BNT, untuk menetukan $\mathrm{LC}_{50}$ dan $\mathrm{LC}_{90}$, data dianalisis menggunakan program Excel.

\section{Persiapan Penelitian}

\section{Ekstraksi tanaman}

Daun A. conyzoides ditimbang masing-masing kemudian dipotong-potong, dicuci dan dikeringanginkan $2-3$ hari kemudian dimasukkan ke dalam wadah dan ditambahkan pelarut methanol teknis. Proses maserasi berlangsung selama 7 hari. Setelah proses maserasi selesai, ekstrak tersebut disaring menggunakan saringan. Larutan hasil saringan dimasukkan ke dalam water bath dengan temperature $64^{\circ} \mathrm{C}$ untuk diuapkan pelarutnya.

\section{Persiapan serangga uji}

Spodoptera sp. dikumpulkan dari areal pertanaman padi kemudian dibawa ke laboratorium untuk dilakukan perbanyakan serangga. Pemeliharaan dan perbanyakan Spodoptera sp dilakukan untuk memperoleh serangga uji dalam jumlah yang cukup dan memenuhi sebagai bahan pengujian. Tanaman padi dimasukkan dalam kurungan serangga yang berukuran 100 x $50 \mathrm{~cm}$ dan disimpan di tempat yang bebas semut.

Larva yang telah terkumpul dipilih berdasarkan ukuran. Larva dengan ukuran yang sama dimasukkan dalam kurungan yang telah berisi tanaman inang. Larva diberi pakan setiap hari berupa tanaman padi fase vegetatif. Pemeliharaan larva dilanjutkan sampai didapatkan larva Instar III dan berukuran seragam yang akan digunakan sebagai serangga uji.

\section{Pengujian ekstrak tanaman}

Pengujian toksisitas dilakukan dengan metode pencelupan daun pakan. Daun tanaman padi fase vegetatif dicelupkan ke dalam ekstrak $A$. conyzoides sesuai perlakuan sedangkan kontrol dicelupkan ke dalam akuades. Sebanyak 10 ekor larva Spodoptera sp. dengan ukuran yang sama diinfestasikan ke dalam cawan yang telah berisi daun padi yang telah diberi perlakuan masing-masing dan diamati pada jam pengamatan 2 jam, 4 jam, 8 jam, 24 jam, 48 jam dan 72 jam. Pengamatan dilakukan dengan menghitung jumlah larva yang mati disetiap jam pengamatan kemudian ditentukan besarnya persen mortalitas.

\section{HASIL DAN PEMBAHASAN}

\section{Mortalitas Larva}

Ekstrak A. conizoides bersifat toksik dan mortalitas larva uji teramati mulai dari 4 jam setelah perlakuan (JSP) ekstrak yaitu pada konsentrasi $1.5 \%$, $2 \%, 2.5 \%$ dan $3 \%$. Pada pengamatan $48 \mathrm{JSP}$, pada semua perlakuan ekstrak telah memperlihatkan mortalitas Spodoptera sp., namun hanya perlakuan Ag $2.5 \%$ dan $3 \%$ yang mampu menyebabkan mortalitas larva uji diatas $90 \%$ setelah 72 jam perlakuan (Tabel $1)$.

Pada pengamatan yang dilakukan, sebelum larva mengalami kematian terdapat gejala awal pada larva berupa bercak hitam pada bagian abdomen (Gambar 1A) selanjutnya tubuh larva seluruhnya menjadi berwarna hitam dan kaku (Gambar 1B).Mortalitas larva Spodoptera sp meningkat sejalan dengan bertambahnya waktu pemaparan ekstrak $A$. conyzoides.

Selain disebabkan oleh sifat toksik dari senyawa yang terkandung dalam ekstrak $A$. conyzoides, mortalitas larva uji juga diakibatkan berkurangnya aktivitas makan larva. Ekstrak $A$. conizoides memiliki aktivitas utama sebagai antifidan dengan konsentrasi penghambatan IC50 sebesar $0,21 \%$ melalui uji dengan pilihan (Ragesh et al., 2016). Ekstrak A. conyzoides bersifat repellent dan feeding deterrent pada hama Tribolium castaneum dan Sitophilus oryzae sebesar $98 \%$ (Amelot et al., 2003). 
Tabel 1. Persentase Mortalitas Spodoptera sp

\begin{tabular}{|c|c|c|c|c|c|c|c|}
\hline \multirow{2}{*}{\multicolumn{2}{|c|}{ Perlakuan }} & \multicolumn{6}{|c|}{ Mortalitas (\%) pada n JSP } \\
\hline & & 2 & 4 & 8 & 24 & 48 & 72 \\
\hline Kontrol & & $0^{\text {tn }}$ & $0^{\text {tn }}$ & $0^{\mathrm{a}}$ & $0^{\mathrm{a}}$ & $0^{\mathrm{a}}$ & $0^{\mathrm{a}}$ \\
\hline Ag $1 \%$ & $(4,00 \mathrm{ppm})$ & $0^{\text {tn }}$ & $0^{\text {tn }}$ & $0^{\mathrm{a}}$ & $0^{\mathrm{a}}$ & $0,03^{\mathrm{a}}$ & $10^{\mathrm{ab}}$ \\
\hline $\mathrm{Ag} 1.5 \%$ & $(4,18 \mathrm{ppm})$ & $0^{\text {tn }}$ & $6.67^{\text {th }}$ & $26.67^{b}$ & $53.33^{b}$ & $53.33^{\mathrm{b}}$ & $53.33^{b}$ \\
\hline $\operatorname{Ag} 2 \%$ & $(4,30 \mathrm{ppm})$ & $0^{\text {th }}$ & $10^{\operatorname{tn}}$ & $43.33^{b c}$ & $60^{\mathrm{b}}$ & $60^{\mathrm{b}}$ & $60^{\mathrm{b}}$ \\
\hline $\operatorname{Ag} 2.5 \%$ & $(4,40 \mathrm{ppm})$ & $0^{\text {tn }}$ & $6.67^{\text {th }}$ & $63.33^{c}$ & $86.67^{c}$ & $86.67^{c}$ & $90^{c}$ \\
\hline Ag $3 \%$ & $(4,48 \mathrm{ppm})$ & $0^{\text {tn }}$ & $10^{\text {tn }}$ & $83.33^{\mathrm{d}}$ & $90^{c}$ & $90^{\mathrm{c}}$ & $96.67^{d}$ \\
\hline
\end{tabular}

Keterangan : Angka-angka yang diikuti huruf yang sama pada kolom yang sama tidak berbeda nyata pada uji BNJ taraf signifikan $5 \%$. JSP : Jam setelah perlakuan.
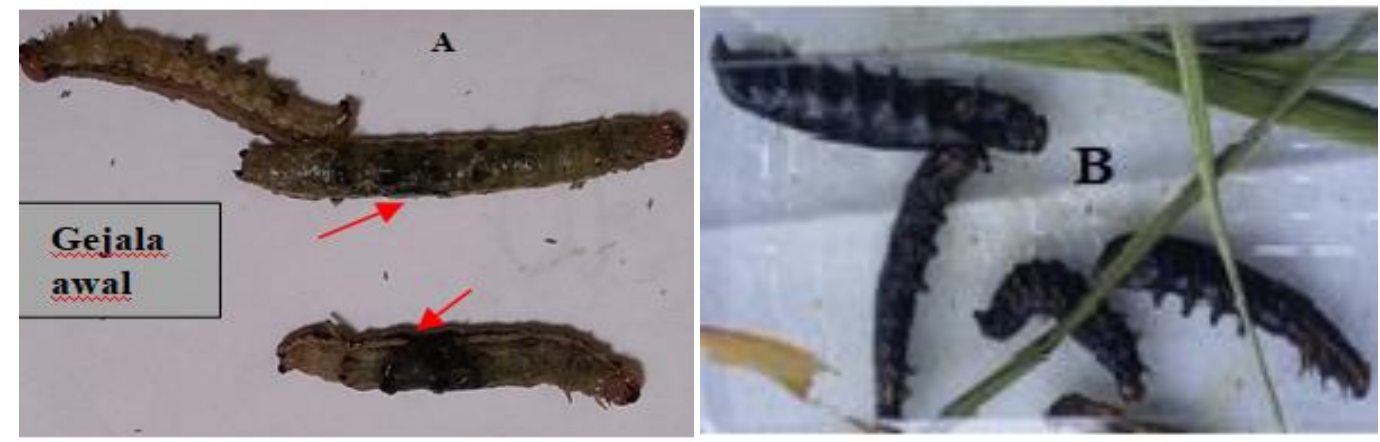

Gambar 1. Gejala awal pada larva Spodoptera sp 1 hari setelah kematian. A : Gejala Awal, B : Gejala pada 5 hari setelah kematian.

Selain itu ekstrak A. conyzoides juga mengandung senyawa-senyawa metabolit sekunder yang apabila dikomsumsi oleh serangga akan meyebabkan kematian. Senyawa kumarin yang terkandung dalam ekstrak $A$. conyzoides memiliki aktivitas insektisida terhadap larva Diaphania hyalinata (Moreira, 2004). Lumowa (2011) melaporkan bahwa mortalitas larva Spodoptera litura tertinggi sebesar $100 \%$ terjadi pada menit ke 60 setelah aplikasi pada $A$. conyzoides ekstrak segar dengan konsentrasi $20 \%$. Mortalitas larva tertinggi didapatkan pada perlakuan ekstrak $A$. conyzoides, hal tersebut terjadi karena tanaman tersebut mengandung bahan aktif yang bersifat racun dan penolak makan (Aldywaridha, 2010).

Kandungan senyawa ekstrak A. conyzoides dari golongan mono dan Sesquiterpene, flavonoid, Chromene, Chromone, Benzofuran, Coumarin, Triterpene, Sterols, dan golongan alkaloid. Ekstrak $A$. conizoydes memiliki bioaktivitas sebagai insektisida, penghambat perkembangan, gangguan hormonal, anti oviposisi dan kemunculan imago terhadap beberapa jenis serangga diantaranya $S$. gregaria, C. maculatus, S. oryzae, T. japonica dan M. domestica (Kamboj \& Saluja, 2008; Sari, et.al., 2021). Hasil penelitian Moreira (2007) menunjukkan bahwa perlakuan ekstrak A. conyzoides terhadap Rhyzopertha dominica mengakibatkan mortalitas serangga uji mencapai $88,67 \%$ dalam jangka waktu 24 jam setelah aplikasi.

\section{Lethal Concentration ( $\mathrm{LC}_{50}$ dan $\left.\mathrm{LC}_{90}\right)$}

Penilaian toksisitas ekstrak A. conyzoides dilakukan dengan menentukan $\mathrm{LC}_{50}$ (konsentrasi ekstrak A.conyzoides yang digunakan untuk membunuh $50 \%$ larva Spodoptera sp. yang diujikan) dan $\mathrm{LC}_{90}$ (konsentrasi ekstrak A.conyzoides yang digunakan untuk membunuh $90 \%$ larva Spodoptera sp. yang diujikan). Penentuan $\mathrm{LC}_{50}$ dan $\mathrm{LC}_{90}$ menggunakan analisis probit. Hasil analisis probit setiap jam pengamatan disajikan pada Tabel 2 .

Tabel 2. Lethal concentration $\left(\mathrm{LC}_{50}\right.$ dan $\left.\mathrm{LC}_{90}\right)$ ekstrak A. conyzoides terhadap larva Spodoptera sp.

\begin{tabular}{ccc}
\hline $\begin{array}{c}\text { Waktu } \\
\text { Pengamatan } \\
\text { (Jam) }\end{array}$ & \multicolumn{2}{c}{ Lethal concentration $(\%)$} \\
\cline { 2 - 3 } & $\mathrm{LC}_{50}$ & $\mathrm{LC}_{90}$ \\
\hline 2 & - & - \\
4 & 3,75 & 5,7 \\
8 & 2,23 & 2,88 \\
24 & 2,03 & 2,58 \\
48 & 1,76 & 2,78 \\
72 & 1,59 & 2,53 \\
\hline
\end{tabular}

Konsentrasi ekstrak A. conyzoides yang diperlukan untuk mematikan $50 \%$ larva Spodoptera sp. dalam jangka waktu 72 jam setelah aplikasi ekstrak yaitu $1,59 \%$ ( $1,59 \mathrm{gr} / 100 \mathrm{ml}$ air $)$ dan konsentrasi untuk mematikan sebanyak $90 \%$ larva Spodoptera sp. dalam jangka waktu 72 jam setelah 
aplikasi ekstrak yaitu 2,53\% (2,53 gr/100 ml air) (Tabel 2). Analisis probit yang telah dilakukan didapatkan persamaan regresi linear $\mathrm{y}=6,3265 \mathrm{x}-$ 21,575 (Gambar 2) berarti setiap kenaikan konsentrasi ekstrak A. conyzoides yang digunakan akan meningkatkan kematian pada larva uji sebesar 21,575.

Ekstrak A. Conizoides telah diuji terhadap beberapa spesies serangga dan menunjukkan hasil yang beragam. Pengujian toksisitas ekstrak $A$. conyzoides terhadap Helicoverpa armigera diperoleh nilai $\mathrm{LC}_{50}$ sebesar 0,17\% (Ragesh, et. al., 2016). Hasil penelitian Yuliani \& Rahayu (2021) tentang toksisitas ekstrak $A$. conyzoides pada konsentrasi $0 \%, 6 \%, 8 \%$, $10 \%$, dan $12 \%$, terhadap $S$. litura diperoleh nilai $\mathrm{LC}_{50}$ berkisar antara 3,45-3,87\%, dan $\mathrm{LC}_{80}$ berkisar antara $7,76 \%-8,18 \%$.

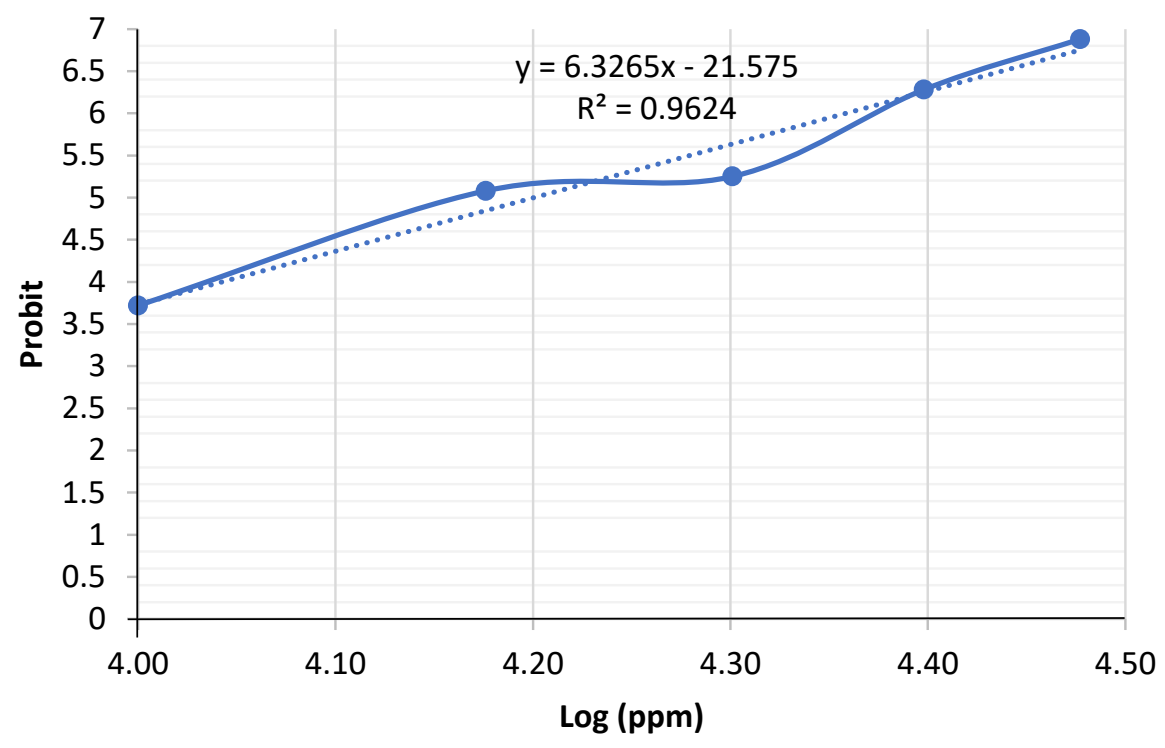

Gambar 2. Grafik hubungan konsentrasi dan mortalitas larva Spodoptera sp.

\section{KESIMPULAN}

Ekstrak A. conyzoides bersifat toksik dan pada konsentrasi $3 \%$ menyebabkan mortalitas yang tinggi seberar $97,6 \%$ pada 72 jam setelah perlakuan. Toksisitas relatif ekstrak memiliki $\mathrm{LC}_{50}$ dan $\mathrm{LC}_{90}$ berturut-turut sebesar $1.59 \%$ dan $2,53 \%$ terhadap larva Spodoptera sp. pada 72 jam setelah perlakuan. Oleh karena itu, ekstrak A. conizoides berpotensi digunakan untuk pengendalian Spodoptera sp. yang menyerang tanaman yang budidayakan.

\section{DAFTAR PUSTAKA}

Aldywaridha. 2010. Uji Efektivitas Insektisida Botani Terhadap Hama Maruca testulalis (Geyer) (Lepidoptera; Pyralidae) Pada Tanaman Kacang Panjang (Vigna sinensis). Jurnal Ilmiah Abdi Ilmu. 3(2).

Amelot MEA, Avendano M, Aubert L, \& Avila JL. 2003. Repellency and feeding deterrence activity of Ageratum conyzoides against the stored grain pests Tribolium castaneum and Sitophilus oryzae. Active plant parts and composition. Scientific Journal Cienca 11(1), 61-76.

Arivoli S, \& Tennyson S. 2013. Antifeedant activity, Developmental Indices and Morphogenetic Variations of Plant Extracts Against Spodoptera litura (Fab) (Lepidoptera:
Noctuidae). Journal of Entomology and Zoology Studies; 1 (4): 87-96.

Chahal R, Nanda A, Akkol EK, Sánchez ES, Arya A, Kaushik D, Dutt R, Bhardwaj R, Rahman Md.H, \& Mittal V. 2021. Ageratum conyzoides L. and Its Secondary Metabolites in the Management of Different Fungal Pathogens. Molecules, 26: 2-28. https://doi.org/10.3390/molecules26102933.

Kamboj A, \& Saluja AK. 2008. Ageratum conyzoides L.: A review on its phytochemical and pharmacological profile. International Journal of Green Pharmacy. 2(2): 59-68.

Lumowa SPP. 2011. Efektivitas Ekstrak Babadotan (Ageratum Conyzoides L.)Terhadap Tingkat Kematian Larva Spodoptera litura F. Eugenia Volume 17 No. 3.

Moreira MD, Picanco MC, Barbosa LCDA, Guedes RNC, Campos MR, Silva GA, \& Martins JC. 2007. Plant compounds insecticide activity against Coleoptera pests of stored products. Pest agropec.bras., Brasília, 42(7): 909-915.

Moreira MD, Picanco M, Barbosa, Guedes RNC, \& Silva. 2004. Toxicity of Leaf Extracts of Ageratum conyzoides to Lepidoptera Pests of Horticultural Crops. Biological Agriculture and Horticulture Vol.22 No. 251. 
Nordlund DA, Jones RL, \& Lewis WJ. 1981. Semiochemicals, Their the role in pest control. John Willey \& Sons. New York.

Ragesh PR, Bhutia TN, \& Singh AK. 2016. Repellent, antifeedant and toxic effects of Ageratum conyzoides (Linnaeus) (Asteraceae) extract against Helicovepra armigera (Hübner) (Lepidoptera: Noctuidae). Archives of Phytopathology and Plant Protection 49(14):19-30.

Sari DE. 2014. Disparitas Bioaktivasi Ekstrak Tanaman Terhadap Kepik Hitam (Paraeucosmetus pallicornis Dallas). Program Pascasarjana, Universitas Hasanuddin. Makassar (Tesis).
Sari DE, Sulfiani, Fitrianti, Kumalasari AS. 2021. Senyawa Tumbuhan Metabolit Sekunder Agen Pengendali Organisme Pengganggu Tumbuhan. Bintang Pustaka Madani. Yogyakarta.

Yadav SK \& Patel S. 2017. Bioactivity of some plant extracts against larvae of Spodoptera litura (Fab.) and Athalia proxima lugens (Klug.) under laboratory conditions. Journal of Entomology and Zoology Studies. 5(2): 14301433.

Yuliani \& Rahayu YS. 2019. The Potency of Ageratum conyzoides as Biopesticide. Proceedings of the Joint Symposium on Tropical Studies (JSTS-19). 11: 419-422. 